\title{
Aquatic Oligochaetes Biodiversity in Turkey: Example of Lake Sapanca with Application of the Biotic Indices
}

\author{
Naime Arslan ${ }^{1}$, Cansev Akkan Kökçü ${ }^{1}$, and Deniz Mercan ${ }^{1}$
}

\begin{abstract}
Turkey is the only country covered almost entirely by three of the world's 34 biodiversity hotspots: the Caucasus, Irano-Anatolian, and Mediterranean. Due to the remarkable variation in its geographic features Turkey is home to 305 Key Biodiversity Areas. Although, Lake Sapanca is one of the most important lakes in Turkey in terms of Important Bird Area (IBA) it has no Ramsar designation as yet.

Oligochaeta sensu stricto, namely clitellates ocur in marine, estuarine, freshwater and terrestrial environs. Despite the ecological importance, freshwater oligochaeta fauna of Turkey still remain under-or even unexplored. Up to now, the aquatic fauna of oligochaetes has not been intensively studied, and only 107 species ( 5 of them endemic) have been reported from different parts of Turkey. And, given that about $43 \%$ of freshwater oligochaete species occurring in Turkey are naidids, about $37 \%$ are tubificin.

This study reports the first assessment of water quality of Lake Sapanca by using benthic macroinvertebrates, physicochemical variables and some metrics (Biological Monitoring Working Party Score (BMWP), Average Score per Taxon (ASPT), Simpson Diversity Index, Shannon-Wiener Diversity Index, Margelef Index and Evennes which are required to implement by European Union Water.

To identify the zoobenthic fauna and water quality of Lake Sapanca, samples were collected seasonally from 9 stations between June 2011 and December 2013. As a result of the study, nineteen takson and 20 oligochaeta species were determined. The water quality of Lake Sapanca was found to be polluted not only biotic indices but also physicochemical parameters. In addition, when we compare the previous study in the same lake we can conclude that Oligochaeta fauna composition and dominancy in the lake changed along ten years.
\end{abstract}

Keywords-ASPT, BMWP, Lake Sapanca, macroinvertebrates.

\section{INTRODUCTION}

Determination of the benthic community composition is a key component for aquatic systems. Oligochaeta, a subclass of the Clitellata, are broadly distributed worldwide and frequently are the most abundant in many freshwater ecosystems and they are widely used for monitoring river and lake pollution. Despite, studies about freshwater oligochaeta have increased in recent years such as, [1], [2], [3], [4], [5], [6] regarding our knowledge of the freshwater oligochaeta fauna of Turkey, large areas still remain under-or even unexplored. Up to now, only 107 species ( 5 of them endemic) have been reported from different parts of Turkey. And, given that about $43 \%$ of

Manuscript received January 2.2016. This work was supported by the Eskişehir Osmangazi University.

N. A. Author is with the Eskişehir Osmangazi University, Science and Art Faculty, Biology Department, Turkey.

C. A. K. is with the Eskişehir Osmangazi University, Science and Art Faculty, Biology Department, Turkey.

D. M. is with the Eskişehir Osmangazi University, Science and Art Faculty, Biology Department, Turkey. freshwater oligochaete species occurring in Turkey are naidines, about $37 \%$ are tubificin.

Turkey has 135 delineated "wetlands of international significance covering 2.2 million ha [7]. Although, Lake Sapanca is one of the most Important Bird Area (IBA) in Turkey, it has no Ramsar designation as yet [8].

Many biotic indices have been established based on macroinvertebrates, because they occupy a central role in the aquatic ecosystem by participating in the decomposition of organic matter and by constituting the major food source for other aquatic invertebrates, fishes, and some birds [9]. The BMWP index was used in several studies to examine the water quality of streams in Turkey [10]-[14]. In addition, instead of direct usage, the BMWP index was adapted for the first time in Turkey for the Yeşilırmak River (Y-BMWP) [12].

The aim of this study is to evaluate the diversity and distribution of fauna of Oligochaeta and to contribute to the Oligochaeta fauna both Lake Sapanca and Turkey.

\section{MATERIAL AND METHODS}

\section{Study Area}

Lake Sapanca is one of the biggest lakes in the province of Adapazari, which is located on the northwest of Turkey (Figure 1). Its surface area is $46.8 \mathrm{~km}^{2}$ with a maximum depth of $55 \mathrm{~m}$. It is $30 \mathrm{~m}$ above sea level, with 13 rivers flowing into the lake and it has one outflowing river. The lake has been used as a source of drinking and process water to the district of Adapazari and as a recreational area.

\section{Sampling}

Samples were taken from Lake Sapanca by Ekman grab and hand dredge between June 2011-December 2013 (Figure 1). Samples of zoobenthos were collected with an Ekman grab sampler $\left(225 \mathrm{~cm}^{2}\right)$, two hauls per station. The samples were washed in the field on a series of sieves with decreasing mesh sizes and preserved in plastic bottles with $70 \%$ or $96 \%$ ethanol. In the laboratory, benthic samples were examined under a stereo binocular microscope and sorted into family or clasis level (only Oligochaeta samples were identified to species level). Sorting of animals proceeded in the laboratory, specimens of Oligochaeta were studied as temporary whole mounts in glycerin or polyvinyl lactophenol. For taxonomical identification of specimens, publications of [15]-[18] were used. In addition, some physicochemical variables of deep water ( $\mathrm{pH}$, temperature, dissolved oxygen, Coductivity) were determined in situ using Multi-Parameter Measurement Device (HQ40d Portable Multiparameter Meter, Hach, US) during the field studies. Other variables $\left(\mathrm{NO}_{3}-\mathrm{N}, \mathrm{NH}_{4}-\mathrm{N}\right.$ and biological oxygen demand (BOD)) were measured in the laboratory by following the standard methods [19]. 


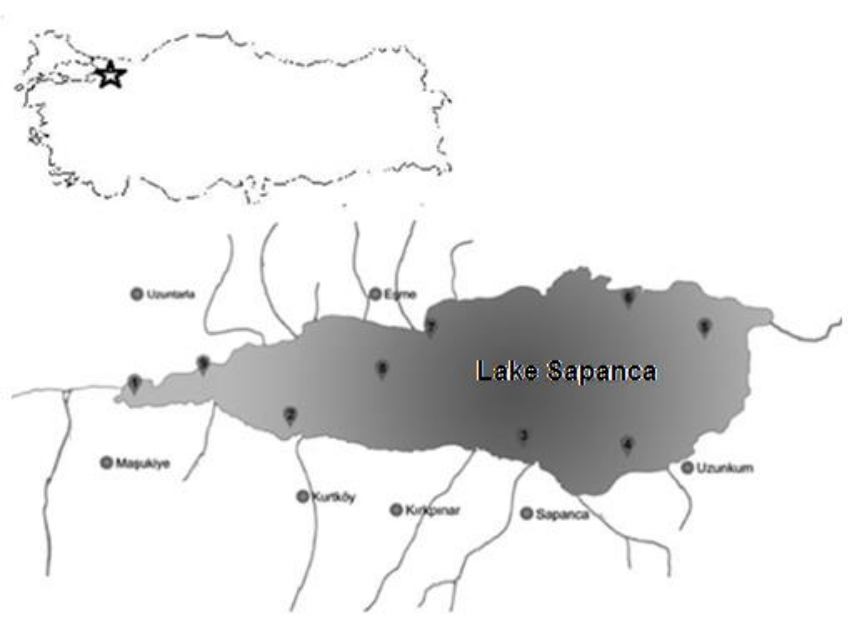

Fig. 1: Geographical situation of the study area and locations of sampling stations.

\section{Data analyses}

In each sampling site revised Biological Monitoring Working Party [20], Average Score Per Taxon (ASPT) [21], Shannon, Simpson diversity and Margelef indices were used to determine water quality based on macroinvertebrates.

\section{RESULTS AND DISCUSSION}

\section{Physicochemical parameters}

The minimum, maximum, and average values of measured physical and chemical variables and water quality classes of the stations during the study period are represented in Table I.

Lake Sapanca has Class II-III water quality [22] according to the physicochemical parameters of collecting sites (Table I). As can see Table I, dissolved oxygen values ranged from 5,1 to $12,92 \mathrm{mg} / \mathrm{L}$ in sites (these values actually not low) but nutrient concentrations, especially amonium nitrogen values ranged between 0,1 and $4,92 \mathrm{mg} / \mathrm{l}$ in sites. This value is high, therefore lake's water quality classified as III (Table I). Reference [23] reported that loading, discharge and accumulation amounts of nitrogen and phosphorus causing eutrophication in the lake, and it had passed to the mesotrophic from oligotrophic state. Our findings showed consistency with these results.

\section{Biological results}

In this study, 32 taxa (20 of them belonging to oligochaeta species) comprising 15,121 individuals were collected in total. The zoobenthos samples from Lake Sapanca contained the following invertebrate groups: Gastropoda (Neritidae, Viviparidae, Melanopsidae, Bithyniade, Lymnaeidae, Physidae, Planorbidae, Valvatidae, Lithoglyphidae), Bivalvia, Nematoda, Oligochaeta, Copepoda, Gammaridae, Chironomidae and, in few numbers, Hirudinae, Odonata, Ceratapogonidae, Simuliidae, Ephemeroptera (Baetidae) and Gammaridae.
TABle I: Physicochemical PARAMETERS AND AVERAGE Water Quality CLASSES (*REPUBLIC OF TURKEY MiNISTRY OF FORESTRY AND WATER AFFAIRS, 2015) FOR STATIONS IN LAKE SAPANCA. AWQ: AVERAGE WATER QUALITY CLASS, ROMEN NUMBER INDICATED WATER QUALITY CLASS.

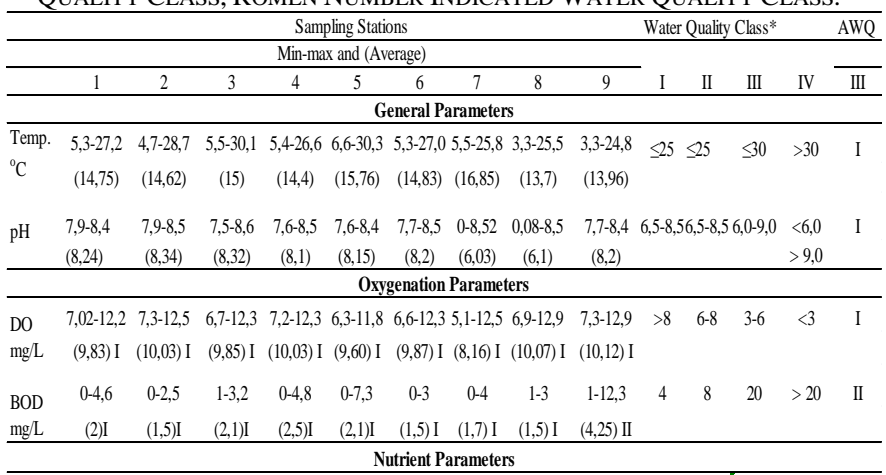

$\mathrm{NO}_{3}-\mathrm{N} \quad 0,11-0,94 \quad 0,09-0,46 \quad 0,05-0,220,04-0,110,06-0,880,07-0,10 \quad 0-0,11 \quad 0,05-0,24 \quad 0,04-0,10<5 \quad 5-10 \quad 10-20>20 \quad \mathrm{I}$

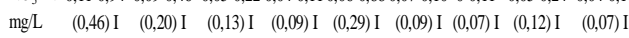

$\mathrm{NH}_{4}{ }^{+} \mathrm{N} \quad 0,11-4,92 \quad 0,11-0,92 \quad 0,14-0,850,14-0,740,13-0,960,15-0,62 \quad 0-0,51 \quad 0,14-2,35 \quad 0,15-0,92<0,2 \quad 0,2-1 \quad 1-2 \quad>2 \quad$ III $\mathrm{mg} / \mathrm{L} \quad(1,54)$ III $\quad(0,59)$ II $\quad(0,53)$ II $\quad(0,47)$ II $(0,54)$ II $(0,42)$ II $(0,29)$ II $(1,14)$ III $\quad(0,46)$ II \begin{tabular}{lllllllllll} 
AWQ & III & II & II & II & II & II & II & III & II \\
\hline
\end{tabular}

Total abundance and species diversity were calculated (Table II) but apparently low.The greatest part of the material was represented by oligochaetes (about 39,24\%) and Gastropoda $(22,72 \%)$. Apart from these dominant groups, Bivalvia comprised $10,68 \%$, Chironomidae $8,86 \%$, all others together about $14,02 \%$ (Table II). The most individuals were collected at station 5 (1092 ind) while the fewest individuals were collected at station 8 (271 ind). Potamothrix hammoniensis $(28,7 \%)$ and L. hoffmeisteri $(5,97 \%)$ were found to have the highest abundance in Oligochaeta. Psammorichtydes albicola and $P$. barbatus have also high abundance (1,67\% and 1,38\% respectively). The number of taxa belonging to invertebrates was the highest at the 1th station while it was the lowest at the 2nd station (Table III).

The 2nd station sandy-stone substrate and lacks vegetation. Therefore low diversity may be explained with these reasons. It is known that some tubificin species, especially Limnodrilus and Tubifex spp., can tolerate bad conditions and they have clearly adapted to a wide range of environmental conditions [15] which is also supported by our results. Genus Potamothrix is widely distributed throughout the world [24] and other genera, Psammoryctides, are distributed in Holarctic [25]. In addition these species considered as a biological indicator of organic pollution and eutrophication and they inhabit together in the same habitats in muddy substrates and their abundance can reach immense sizes in aquatic systems with high trophy levels [15], [26].

Dominant and the most abundant species, Potamothrix hammoniensis known as freshwater euryhaline form and this species reported in several studies from eutrophic lowland lakes in Europe. 
TABLE II: DISTRIBUTIONS AND DOMINANCE (\%) OF MACROINVERTEBRATES AT THE STATIONS.

\begin{tabular}{|c|c|c|c|c|c|c|c|c|c|}
\hline \multirow[b]{2}{*}{ Taxa } & \multicolumn{9}{|c|}{ Sampling Stations } \\
\hline & 1 & 2 & 3 & 4 & 5 & 6 & 7 & 8 & 9 \\
\hline \multicolumn{10}{|l|}{ Gastropoda } \\
\hline Neritiade & - & - & - & - & 3,3 & 3,51 & 0,58 & - & - \\
\hline Viviparidae & 0,36 & - & - & - & 0,09 & - & 0,19 & - & 0,29 \\
\hline Melanopsidae & 0,24 & 0,33 & - & 0,21 & 2,38 & 3,14 & 2,14 & - & - \\
\hline Bithynidae & 1,82 & - & - & - & 2,66 & 2,31 & 0,19 & - & - \\
\hline Lymnaeidae & 2,78 & - & 1,1 & - & 0,46 & 1,02 & - & - & 0,29 \\
\hline Physidae & 4,48 & - & 2,2 & - & 0,37 & 2,95 & 1,17 & - & 0,29 \\
\hline Planorbiade & 2,66 & - & 1,1 & - & 3,57 & 2,4 & 2,14 & - & 0,88 \\
\hline Valvatidae & 11,14 & 1,66 & - & 0,21 & 64,19 & 55,22 & 11,07 & 0,37 & 3,22 \\
\hline Hydrobiidae & 0,12 & - & - & - & 2,47 & - & 0,97 & - & 0,29 \\
\hline Bivalvia & 4,72 & - & 2,42 & - & 12,73 & 14,22 & 14,95 & - & 47,08 \\
\hline Nematoda & - & 15,23 & - & 1,68 & - & - & - & 5,17 & - \\
\hline \multicolumn{10}{|l|}{ Oligochaeta } \\
\hline Aulodrillus pluriseta & - & - & - & - & - & - & - & - & 0,29 \\
\hline Dero digitata & - & - & - & - & - & - & 0,19 & - & - \\
\hline Ophidonais serpentina & - & - & - & - & - & - & 0,39 & - & - \\
\hline Nais elinguis & 0,85 & - & - & - & - & - & - & - & - \\
\hline Nais communis & 0,61 & - & - & - & - & - & - & - & - \\
\hline Limnodrilus cervix & - & 0,33 & - & - & - & - & - & - & - \\
\hline Limnodrilus claperadeanus & 0,97 & 0,66 & 0,22 & - & 0,09 & - & 0,19 & 0,37 & - \\
\hline Limnodrilus hoffmeisteri & 13,2 & 18,54 & 3,52 & 0,42 & 0,37 & 0,92 & 7,18 & 4,06 & 5,56 \\
\hline Limnodrilus udekemianus & 0,12 & - & - & - & - & 0,37 & 0,19 & - & - \\
\hline Potamothrix hammoniensis & 16,34 & 49,34 & 53,74 & 34,11 & 4,49 & 3,51 & 45,24 & 37,27 & 14,04 \\
\hline Potamothrix heuscheri & - & - & - & 0,21 & - & - & - & - & - \\
\hline Psammoryctides albicola & 0,36 & 0,33 & 1,1 & 0,21 & - & 1,29 & 1,17 & 1,48 & 9,06 \\
\hline Psammoryctides barbatus & 0,36 & 1,99 & 0,66 & 2,74 & - & 0,28 & 2,14 & 0,74 & 3,51 \\
\hline Psammoryctides deserticola & 0,24 & - & - & - & - & - & - & - & 0,29 \\
\hline Psammoryctides moravicus & 0,12 & 0,99 & 0,66 & 0,84 & - & 0,18 & 0,58 & 2,21 & - \\
\hline Tubifex tubifex & - & - & 0,44 & 0,21 & - & - & - & - & - \\
\hline Enchytraeidae spp. & - & - & - & - & - & 0,18 & - & - & - \\
\hline Trichodrillus sp. & 0,36 & - & - & - & - & - & - & - & - \\
\hline Rhynchelmes sp. & - & - & - & - & - & 0,09 & - & - & 0,29 \\
\hline Quistradrilus multisetosus & - & - & - & 0,21 & - & - & - & - & 0 \\
\hline Hirudinae & - & - & - & - & 0,09 & - & - & - & 1,75 \\
\hline Copepoda & 5,45 & - & - & - & - & - & - & 45,76 & 0 \\
\hline Gammaridae & 1,21 & - & - & 0,21 & - & - & - & - & 0,58 \\
\hline Cyclopidae & - & - & 26,87 & 58,74 & - & 0,09 & - & - & - \\
\hline \multicolumn{10}{|l|}{ Ephemeroptera } \\
\hline Baetidae & - & - & 0,66 & - & - & 0,18 & - & 0,74 & - \\
\hline Chironomidae & 30,51 & 10,6 & 5,07 & - & 2,75 & 8,13 & 9,32 & 1,11 & 12,28 \\
\hline Ceratapogonidae & 0,97 & - & 0,22 & - & - & - & - & - & - \\
\hline Simuliidae & - & - & - & - & - & - & - & 0,74 & - \\
\hline
\end{tabular}

Several studies data show that in the Pliocene, macroinvertebrates fauna were widely distributed in different geographic parts of the Palearctic, via the basins of the Rivers Danube and Volga, the Black Sea region, and Western Siberia. During the Pleistocene, most representatives of the genus expired or were forced out by glaciers to downstream parts of rivers belonging to basins of the Black Sea and Azov Sea. It is known that in Europe, the Caspian and Ponto-Azovian fauna have spread in different ways to Turkey (via Aral basin, Euphrates river, European river systems and the Adriatic Sea [27]. In addition, Southern corridor, one of the most important principal invasion corridors exist in Europe, links the Black Sea basin with the North Sea basin via the Danube Main Rhine waterway, including the Main-Danube Canal and the length of the corridor from the Black Sea (Sulina Arm) up to the North Sea is about $3500 \mathrm{~km}$ [28]. The modern pattern of Potamothrix hammoniensis distribution in Europe and Turkey implies that the Southern corridor could have been the main routs of its migration. From the information provided, we can conclude that the Danubian and some lakes fauna of Turkey (at least in Marmara and Aegean region) associated. Reference [5] indicated that Danube River Delta's lakes Oligochaeta communities comprise between $7.9 \%$ and $36.2 \%$ of the total biomass of benthic fauna and among them $P$. hammoniensis was the more efficient under hypertrophic conditions. Present study results show that Oligochaeta fauna of Lake Sapanca similar to of Danube River Delta's lakes.

Previous study in the same Lake [5], 13 species were found, of which 11 tubificin and 2 naidid species.They were reported that the most abundant species were Tubifex tubifex (707 ind. $\mathrm{m}^{-2}$,) and Psammoryctides barbatus $\left(243\right.$ ind. $\left.\mathrm{m}^{-2}\right)$. It was shown in the previous study that Oligochaeta were also dominant groups but it was seen that the dominancy and composition changed along ten years.

TABLE III: VALUES OF INDICES OF THE SITES AT LAKE SAPANCA (ROMEN NUMBER INDICATED WATER QUALITY CLASS).

\begin{tabular}{lccccccccc}
\hline \multicolumn{10}{c}{ Sampling sites } \\
\hline Indices & 1 & 2 & 3 & 4 & 5 & 6 & 7 & 8 & 9 \\
\hline Taxa number & 24 & 11 & 15 & 13 & 15 & 19 & 19 & 12 & 17 \\
BMWP score & 27 (IV) & 6 (V) & $16(\mathrm{IV})$ & 1 (V) & 21 (IV) & 25 (IV) $18(\mathrm{IV})$ & $12(\mathrm{IV})$ & 18 (IV) \\
ASPT & $3,38(\mathrm{IV})$ & 2 (IV) & 2,6 (IV) & 1 (IV) & 3 (IV) & 3,1 (IV) 3 (IV) & 3 (IV) & 3 (IV) \\
Shannon Index & 2,231 & 1,467 & 1,429 & 1,001 & 1,378 & 1,664 & 1,834 & 1,355 & 1,756 \\
Simpson Index & 0,8409 & 0,687 & 0,634 & 0,538 & 0,565 & 0,663 & 0,745 & 0,646 & 0,73 \\
Evenness & 0,3877 & 0,394 & 0,278 & 0,209 & 0,265 & 0,278 & 0,33 & 0,323 & 0,341 \\
Margalef & 3,424 & 1,751 & 2,288 & 1,947 & 2,001 & 2,576 & 2,883 & 1,964 & 2,742 \\
\hline
\end{tabular}

The values of Simpson Diversity Index, Shannon-Wiener Diversity Index and Margalef Diversity Index varied between, 0,53 and 0,$84 ; 1$ and 2,23; 1,34 and 3,42 respectively (Table III). The lowest values were recorded at Site 4 , the highest values at Site 1 in all three diversity indices. Low diversity of benthic macroinvertebrate community can emphasizes the environmental degradation. The diversity indices values decreases with negative environmental changing. According to the Reference [29] the level of diversity of invertebrate is important to define ecological status of aquatic ecosystems.

In the present study, the observed high abundance of pollution-tolerant oligochaets (Potamothrix spp, Limnodrilus spp. and Psammoryctides spp.-see Table II) indicated poor water quality of the lake (characterized by low dissolved oxygen and high nutrient concentrations). Although, dissolved oxygen levels of the lake not low but high value of some Ammonium ions might be limiting for many species, these conditions favoured Potamothrix, Limnodrilus, some Gastropods and Chironomids [30]-[31] (Kelly-Quinn, 2003; Naguma et al, 2004).

\section{CONCLUSION}

Oligochaeta spp. ocur in marine, estuarine, freshwater and terrestrial environs. Around the world about 1.700 valid species of aquatic oligochaetes are known to date; of these, about 1.100 are freshwater. Despite the ecological importance, freshwater oligochaeta fauna of Turkey still remain under-or even unexplored. Up to now, the aquatic fauna of oligochaetes has not been intensively studied, and only 107 species, of which five of them were described as new species [32-34] have been reported from different parts of Turkey. And, given that about $43 \%$ of freshwater oligochaete species occurring in Turkey are naidids, about $37 \%$ are tubificin. Because of the limited information, it is impossible to speculate about extensive zoogeographical aspects. The collected data show that Oligochaeta fauna of Turkey is composed of cosmopolitan or widely distributed species, while Haplotaxidae, Lumbriculidae and Criodrilidae have small numbers of species. According to 
literature data, the most recorded genera are Pristina, Nais and Dero accompanied by Potamothrix, Psammoryctides, Tubifex and Limnodrilus. Timm [35] divided the Holoarctic region into six subregions, on the basis of the distribution of oligochaetes, the Euro-Siberian, West Balkan, Ponto-Caspien (brackish water), East Siberian, Pacific and Atlantic ones. As we indicated in result and discussion section, according to modern pattern of the most recorded genera distribution of oligochaetes in Europe and Turkey implies that the Danubian and some lakes-rivers fauna of Turkey (at least in Marmara and Aegean region) associated.

As we emphasized before Lake Sapanca is one of the most important lakes in Turkey in terms of Important Bird Area (IBA) but it has no Ramsar designation as yet. In addition loading, discharge and accumulation amounts of nitrogen and phosphorus causing eutrophication in the lake, and it had passed to the mesotrophic from oligotrophic state [23]. Our findings showed consistency with these results. Consequently, our findings for both physicochemical parameters and zoobenthic organisms indicate that the water quality of this lake is polluted.

In addition, biotic and diversity index results can emphasizes the environmental degradation. In the study which was performed by [5] in the same Lake, 13 species were found of which six of them were also found in the present study, seven of them were not found; in addition in the present study fourteen taxa determined new for lake Oligochaeta fauna. When we compare two studies results we can conclude that fauna dominancy and composition of Oligochaeta in the lake changed along ten years.

Only measuring some physicochemical parameters of water, we cant assess general health of aquatic systems, freshwaters organisms should be considered to be informed about general health of freshwater life. For this, biotic indices should be used for water quality and health of surface water studies. Aim of EU Water Framework Directive (Council of European Communities 2000) is to achieve ecological quality of all waters (inland surface waters, transitional (=estuarine) waters, coastal waters and groundwater). In Turkey, several biotic index studies were done and stil in progress. There is still a need for further intensive study and testing of the effectiveness of the BMWP and ASPT indices. These indices may require adaptation for Turkey based on its geomorphological and environmental features.

\section{REFERENCES}

[1] S. Yıldız, A. Tasdemir, M. Ozbek, S. Balık and M.R. Ustaoglu, "Macrobenthic Fauna of Lake Eğrigöl (Gündoğmuş- Antalya), “ Turk. J. Zoology, vol.29, pp.275-282, 2005.

[2] B. Camur-Elipek, N. Arslan, T. Kirgiz and B. Oterler, "Benthic Macrofauna in Tunca River (Turkey) and Their Relationships with Environmental Variables," Acta Hydrochimica et Hydrobiologica, vol. 34, pp.360-366, 2006. http://dx.doi.org/10.1002/aheh.200500631

[3] S. Yildız and S. Balık, "The Oligochaeta (Annelida) Fauna of Topçam Dam-Lake (Aydın-Turkey)," Turk. J. Zoology, vol.30(1), pp.83-89, 2006.

[4] S. Yıldı, M.R. Ustaoglu and S. Balık, "Littoral Oligochaeta (Lumbriculidae and Enchytraeidae) communities of some mountain lakes in the Eastern Black Sea range (Turkey)," Zoology in the Middle East, Supplementum 2, Advances in Earthworm Taxonomy, pp. 151-160, 2010.

[5] S.K. Şahin and S. Yıldız, "Species distribution of oligochaetes related to environmental parameters in Lake Sapanca (Marmara Region, Turkey),"
Turkish Journal of Fisheries and Aquatic Sciences, vol.11(3), pp.359-366, 2011.

[6] B. Çamur-Elipek, N. Arslan, T. Kırgız, B. Öterler, H. Güher and N. Özkan, "Analysis of Benthic Macroinvertebrates in Relation to Environmental Variables of Lake Gala (Edirne/Turkey)", Turkish Journal of Fisheries and Aquatic Sciences, vol.10(2), pp.235-243, 2010. http://dx.doi.org/10.4194/trjfas.2010.0212

[7] GDNCNP, General Directorate of Nature Conservation and National Parks Sulak alanlar(Wetlands),

<http://www.milliparklar.gov.tr/dkmp/anasayfa/2010.

[8] BirdLife International, Important Bird Areas and potential Ramsar Sites in Europe. BirdLife International, Wageningen, The Netherlands, 2001.

[9] M. Callisto, P. Moreno and F.A.R. Barbosa, "Habitat diversity and benthic functional trophic groups at Serra do Cipo, southeast Brazil," Rev Bras Biol, vol. 61, pp. 259-266, 2001. http://dx.doi.org/10.1590/S0034-71082001000200008

[10] N. Kazanc1, S. Girgin, M. Dugel and D. Oğuzkurt, Inland Waters of Turkey Series II: Biotic Index Methods for Evaluating Environmental Quality of Running Waters; Ankara, Turkey: Imaj Press, 1997, ch.2

[11] N. Kazanc1, P. Ekingen, G. Türkmen, Ö. Ertunç, M. Dügel and Y. Gültutan, "Assessment of ecological quality of Aksu Stream (Giresun, Turkey) in Eastern Black Sea Region by using Water Framework Directive (WFD) methods based on benthic macroinvertebrates," Review of Hydrobiology, vol. 3(2), pp. 165-184, 2010.

[12] N. Kazanc1, G. Turkmen, P. Ekingen and O. Başoren, "Preparation of a biotic index (Yeşilırmak-BMWP) for water quality monitoring of Yeşilırmak River (Turkey) by using benthic macroinvertebrates," Review of Hydrobiology, vol. 6, pp. 1-29, 2013.

[13] M. Duran, "Monitoring water quality using benthic macroinvertebrates and physicochemical parameters of the Behzat Stream (Tokat, TURKEY)," Pol J Environ Stud, vol. 15, pp. 709- 717, 2006.

[14] H. Kalyoncu and M. Zeybek, " An application of different biotic and diversity indices for assessing water quality: a case study in the rivers Cukurca and Isparta (Turkey)," Afr J Agric Res, vol. 6, pp. 19-27, 2011.

[15] R.O. Brinkhurst and B.G.M. Jamieson, Aquatic Oligochaeta of the World; Toronto University, Toronto, 1971.

[16] R.O. Brinkhurst and M.J. Wetzel, Aquatic Oligochaeta of the World: Supplement A Catalogue of New Freshwater Species, Descriptions and Revisions; Canadian Technical Report of Hydrography and Ocean Sciences, Canada, 1984.

[17] R.D. Kathman and R.O. Brinkhurst, Guide to the Freshwater Oligochaetes of North America; Aquatic Resources Center, USA, 1998.

[18] T. Timm, A Guide to the Estonian Annelida. Naturalist's Handbooks 1; Estorian Acedemy Publishers, Tallinn, 1999.

[19] APHA, Standard Methods for the Examination of Water and Wastewater, Washington; American Public Health Association, 1998.

[20] M.F. Paisley, D.J. Trigg and W.J. Walley, "Revision Of The Biological Monitoring Working Party (BMWP) Score System: Derivation Of Present-Only And Abundance-Related Scores From Field Data," River Res. Applic, doi: 10.1002/rra.2686, 2013. http://dx.doi.org/10.1002/rra.2686

[21] P.D. Armitage, D. Moss, J.F. Wright and M.T, "Furse, The Performance of a new Biological Water Quality Score System Based on Macroinvertebrates Over a Wide Range of Unpolluted Running-Water Sites," Wat. Res. Vol. 17, pp.333-347, 1983. http://dx.doi.org/10.1016/0043-1354(83)90188-4

[22] Republic of Turkey Ministry of Forestry and Water Affairs, Surface Water Quality Management Regulation (YSKYY), 29320 Official Journal, Ankara, 2015.

[23] H. Arman, R. Ileri, E. Dogan and B. Eren, "Investigation of Lake Sapanca water pollution, Adapazari, Turkey, " International Journal of Environmental Studies, vol. 66(5), pp. 547-561, 2009. http://dx.doi.org/10.1080/00207230902842776

[24] M.J. Wetzel, R.D. Kathman, S.V. Fend and K.A. Coates, "Taxonomy, systematics, and ecology of freshwater Oligochaeta, "Workbook prepared for North American Benthological Society Technical Information Workshop, 48th Annual Meeting, Keystone Resort, 2000.

[25] T. Timm and H.H. Veldhuijzen vanZanten, Freshwater Oligochaeta of North-West Europe; World Biodiversity Database, CD-ROM Series. Expert Center for Taxonomic Identification, University of Amsterdam, 2002.

[26] T. Timm, A. Seire and P. Pall, "Half a century of oligochaeta research in estonian running waters," Hydrobiologia, vol. 463, pp.223- 234, 2001. http://dx.doi.org/10.1023/A:1013176229631 
[27] H. Ojaveer, E. Leppakoski, S. Olenin and A. Ricciardi, "Ecological impact of Ponto-Caspien invader in the Baltic Sea, Eurepean inland waters and the Great Lakes: an inter-ecosystem comparison, Invase Aquatic species in Europe; Kluwer Academic Publication, 2002.

[28] V.E. Panov, B. Alexandrov, K. Arbaciauskas, R. Binimelis, G.H. Copp, M. Grabowski, F. Lucy, , R.S, Leuven, S. Nehring, M. Paunovic, V. Semenchenko and M.O. Son, "Assessing the Risks of Aquatic Species Invasions via European Inland Waterways: From Concepts to Environmental Indicators," Integrated Environmental Assessment and Management, vol. 5(1), pp. 110-126, 2009. http://dx.doi.org/10.1897/IEAM_2008-034.1

[29] Council of European Communities, Water Framework Directive (WFD) Directive 2000/60/EC of the European Parliament and of the Council of 23 October 2000 establishing a framework for Community action in the field of water policy. Official Journal of the European Communities L 327, 22.12.2000, 1-72, 2000.

[30] Kelly-Quinn, C. BRADLEY, D. MURRAY, P. ASHE, J. BRACKEN and M. McGARRIGLE, "Physico-chemical characteristics and macroinvertebrate communities of the Caher River, "Royal Irish Academy., vol. 103, pp. 187-196, 2003. http://dx.doi.org/10.3318/BIOE.2003.103.3.187

[31] T. NAGUMO, K.P. WOLI and P. HATANO, "Evaluating the contribution of point and non point source of nitrogen pollution in the stream water in a rural area of central Hokkaido, Japan," Soil Science and Plant Nutrition, vol. 50(1), pp.109-117, 2004. http://dx.doi.org/10.1080/00380768.2004.10408458

[32] N. Arslan, T. Timm and C. Erséus "Aquatic Oligochaeta (Annelida) of Balıkdamı wetland (Turkey),with description of two new species of Phallodrilinae," Biologia, vol.62(3), pp. 323-334, 2007. http://dx.doi.org/10.2478/s11756-007-0055-y

[33] T. TIMM, N. ARSLAN, M. RÜZGAR, S. MARTINSSON and C. ERSÉUS, "Oligochaeta (Annelida) of the profundal of Lake Hazar (Turkey), with description of Potamothrix alatus hazaricus n. ssp.," Zootaxa, vol. 3716(2), pp. 144-156, 2014.

[34] L. Matamoros, S. Yıldiz and C. Erseus, "A new species within the genus Marionina (Enchytraeidae:Annelida:Clitellata) from the southern Black Sea," Marine Biology Research, vol. 3(6), pp. 397-402, 2007. http://dx.doi.org/10.1080/17451000701694844

[35] T. Timm, Aquatic Oligochaeta Biology, New York, 1980, pp. 55-77.

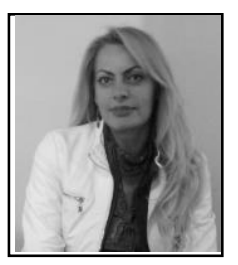

Naime Arslan, Eskişehir, 22/08/1970. MSc: Anadolu University, Science Faculty, Biology Department; PhD:Eskisehir Osmangazi University, Science and Art Faculty, Biology Department. Professor Dr. from 2012 in Eskisehir Osmangazi University, Biology Department, Turkey. Major field of study freshwater macroinvertebrates, freshwater ecology and pollution.

She is head of the Hydrobiology Department. Her research interests are mainly focused on taxonomy and ecology of freshwater invertebrates (especially Oligochaeta and Chironomidae), freshwater pollution and particularly the impact of water pollution on distribution of freshwater invertebrates.

Previous publication

N. Arslan, "Invisible face of boron pollution in fluvial ecosystem: the level in the tissues of sentinel and nectonic organisms, "Ambio, DOI: 10.1007/s13280-013-0383-9. 2013.

D.A. Odabaşı and N. Arslan, "A New Species of Bithynia (Gastropoda: Bithyniidae) from an Eutrophic Lake Uluabat (South Marmara Region), Northwest of Turkey," Turkish Journal of Fisheries and Aquatic Sciences, vol. 15, pp. 371-375, 2015. 